\title{
GREEN SYNTHESIS, CHARACTERIZATION OF SILVER NANOPARTICLES OF A MARINE RED ALGA SPYRIDIA FUSIFORMIS AND THEIR ANTIBACTERIAL ACTIVITY
}

\author{
SUBBIAH MURUGESAN ${ }^{*}$, SUNDARESAN BHUVANESWARI', VAJIRAVELU SIVAMURUGAN² \\ ${ }^{1}$ Division of Algal Biotechnology and Bionano Technology, PG and Research Department of Botany, Pachaiyappa's College, Chennai \\ 600030, India, ${ }^{2} \mathrm{PG}$ and Research Department of Chemistry, Pachaiyappa's College, Chennai 600030, India \\ Email: sivaatnus@gmail.com,smurugesan5@gmail.com \\ Received: 15 Jan 2017 Revised and Accepted: 31 Mar 2017
}

\begin{abstract}
Objective: In the present system, the green synthesis of silver nanoparticles using marine the red alga Spyridia fusiformis and antibacterial activity was carried out.

Methods: The seaweed extract was used for the synthesis of AgNPs at room temperature. The silver nanoparticles were characterized by using UVVisible spectroscopy, Fourier transform infrared spectroscopy, transmission electron microscope and X-ray diffraction (XRD) techniques. The antibacterial activity of biosynthesized silver nanoparticles was carried out by disc diffusion method against pathogenic bacteria.

Results: The UV-visible spectroscopy revealed surface plasmon resonance at $450 \mathrm{~nm}$. The FT-IR measurements showed the possible functional groups responsible for the formation of nanoparticles. The X-ray diffraction analysis showed that the particles were crystalline in nature. TEM micrograph has shown the formation of silver nanoparticles with the size in the range of 5-50 nm. The silver nanoparticles synthesized from the S. fusiformis showed higher activity and proved their efficacy in controlling the pathogenic bacterial strains. The nanoparticles showed highest inhibition activity on $K$. pneumaniae and S. aureus up to 26 and $24 \pm 0.01 \mathrm{~mm}$ at $100 \mu \mathrm{g} / \mathrm{ml}$ of nanoparticles.
\end{abstract}

Conclusion: The synthesised AgNPs have shown the best antibacterial activity against human pathogens E. coli, K. pneumoniae, S. aureus and P. aeruginosa. The above eco-friendly AgNPs synthesis procedure could be a viable solution for industrial applications in the future and therapeutic needs.

Keywords: Antibacterial activity, Green synthesis, Marine algae, Silver nanoparticles, Spyridia fusiformis

(C) 2017 The Authors. Published by Innovare Academic Sciences Pvt Ltd. This is an open access article under the CC BY license (http://creativecommons.org/licenses/by/4.0/) DOI: http://dx.doi.org/10.22159/ijpps.2017v9i5.17105

\section{INTRODUCTION}

Nanoparticles are being viewed as the fundamental building blocks of nanotechnology. The most important and distinct property of nanoparticles is that they exhibit larger surface area to volume ratio. Metal nanoparticles have tremendous applications in the area of catalysis, photo electronics and diagnostic biological probes and also in display devices. Among the metal nanoparticles, silver nanoparticles play a significant role in the field of biology and medicine.

In the current scenario, the biological synthesis of the metallic nanoparticle is gaining more interest, as it is reliable and ecofriendly. The previous literature survey revealed that the nanoparticle synthesis using biological sources like algae has been unexplored and unexploited [1-11].

Nanosilver (silver nanoparticle, AgNP) material has a wide range of applications. Because of the effective antimicrobial nature and low toxicity to mammalian cells, AgNPs have become one of the most commonly used nanomaterials in consumer products (104 out of 502 nanoproducts surveyed) [12]. The antibacterial activity of the silvercontaining materials can be used in some medicines to reduce infections as well as to prevent bacterial colonization. The present study evaluated the biosynthesis and characterization of silver nanoparticles of $S$. fusiformis and investigated their antibacterial potential.

\section{MATERIALS AND METHODS}

\section{Chemicals and bacterial cultures}

The chemicals employed in the present study such as silver nitrate was AR grade and purchased from SRL (India) and used as such without further purification. All glasswares and quick fits used in the experimental work were made up of corning/borosil glass. These glasswares were washed thoroughly and dried in hot air oven before use. Bacterial cultures Escherichia coli (ATCC 10798), Klebsiella pneumaniae (ATCC 31488), Staphylococcus aureus (ATCC 10832D5), Pseudomonas aeruginosa (ATCC 207), were purchased from M/s. LGC Promochem India Pvt. Ltd, Bangalore, India.

\section{Collection of seaweed}

The marine red seaweed Spyridia fusiformis was collected from a depth of 2.5 meters in the rapid island Gulf of Mannar, near the Mandapam Coastal area in South India (co-ordinates: $9^{\circ} 16^{\prime} 48^{\prime \prime} \mathrm{N}$, $79^{\circ} 7^{\prime} 12^{\prime \prime} \mathrm{E}$ ).

\section{Preparation of algal extract}

Collected red seaweed was washed with seawater to remove the epiphytes and sand particles. After dried, $1 \mathrm{~g}$ of materials was cut into small pieces; ground with $50 \mathrm{ml}$ of distilled water with mortar and pestle and these extracts were boiled for $5 \mathrm{~min}$. The boiled extract was filtered through a high-quality Whatman1filter paper and the supernatant was used and stored at $4{ }^{\circ} \mathrm{C}$ for further process.

\section{Biosynthesis of silver nanoparticles}

In the typical synthesis process of silver nanoparticles, $10 \mathrm{ml}$ of aqueous algal extract was added with $90 \mathrm{ml}$ of $1 \mathrm{mmol}$ of silver nitrate solution in $250 \mathrm{ml}$ conical flask. The reaction mixture was kept at room temperature under mechanical stirring [4-8].

\section{Characterization of silver nanoparticles}

Biogenic synthesis of nano silver was monitored using a UV-visible spectroscopy (UV-1601 Shimadzu spectrophotometer). After the complete reduction of silver ions by the $S$. fusiformis extract, it was analyzed by FT-IR spectroscopy. XRD pattern of dry nano silver powder was acquired by $\mathrm{CuK}_{\alpha}$ radiation (1.5406 $\left.\AA ; 5 \mathrm{kV}, 30 \mathrm{~mA}\right)$. It was also analyzed to determine peak intensity, position and width. The size and shape of the biosynthesized nanoparticles were observed using a transmission electron microscope (TEM) (Hitachi, Model: S-3400N). 


\section{Antibacterial activity}

Antibacterial activity of $S$. fusiformis assisted, silver nanoparticles were carried out using disc diffusion method against pathogenic bacteria. These bacterial cultures were freshly cultivated for $24 \mathrm{~h}$ in nutrient broth. Each bacterial culture was spread on the Muller Hinton agar plates. Sterile paper discs containing three different concentrations of silver nanoparticles were placed and incubated. After $24 \mathrm{~h}$ of incubation, the zone formation was recorded. The experiments were repeated for three times.

\section{Statistical analysis}

The data obtained in the present study were analyzed by using the one-way ANOVA with equal sample size by using SPSS 17.0.

\section{RESULTS}

\section{Biosynthesis of silver nanoparticles}

The shade-dried biomass of the marine red alga S. fusiformis was used for the synthesis of silver nanoparticles. Reduction of $\mathrm{AgNO}_{3}$ was visually observed from the change in reaction mixture colour from transparent to brownish yellow after 30 min of reaction (Fig. 1). The intensity of brown colour gradually intensified in direct proportion to the reaction period. Also, the colour of the solution gradually intensified on heating, which indicates the formation of Ag nanoparticles. In the case of the negative control (silver nitrate solution only), no change in colour was observed [9-11].

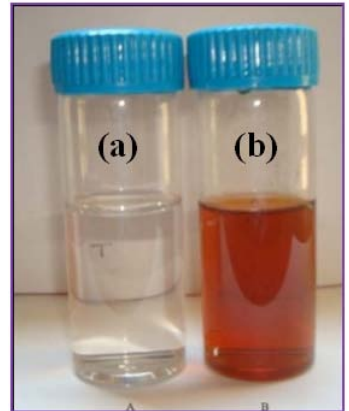

Fig. 1: The test tube containing the filtrate of the $S$. fusiformis biomass in aqueous solution of $1 \times 10^{-3} \mathrm{M}$ silver nitrate at the (a) beginning of reaction and (b) after $2 \mathrm{~h}$ of reaction

\section{Characterization of silver nanoparticles UV-visible spectroscopy}

UV-Visible spectroscopy is an important technique to determine the formation and stability of metal nanoparticles in an aqueous solution. The extracellular synthesis of silver nanoparticles using $S$. fusiformis involved by the reduction of $\mathrm{Ag}^{+}$ions was identified by the UV-Visible spectroscopy. The characteristic absorption peak observed at $450 \mathrm{~nm}$ in UV-Visible spectrum for S. fusiformis (Fig. 2) indicated the formation of AgNPs.

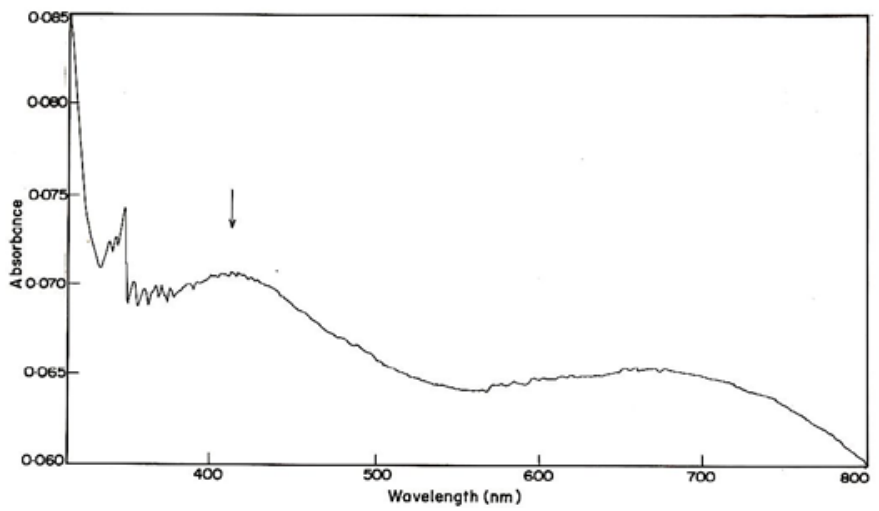

Fig. 2: UV-Visible-spectra of silver nanoparticles synthesized from extract of $S$. fusiformis

\section{FT-IR spectroscopy}

The FT-IR spectrum recorded for silver nanoparticles synthesized using S. fusiformis biomass, showed a variation in the intensity of bands in different regions (Table 1). A number of broad bands were observed in the region of $3907,3779,3410,2927,2853,2593,1644$, 1416, 1170 and $749 \mathrm{~cm}^{-1}$ (Fig. 3).

The peak at 3907 and $3779 \mathrm{~cm}-1$ was assigned to the vibrational modes of the- $\mathrm{O}-\mathrm{H}$ stretching vibrations of the phytochemical molecules. The peak at $3410 \mathrm{~cm}^{-1}$ corresponds to- $\mathrm{N}-\mathrm{H}$ stretching vibrations. The peaks at 2927 and $2853 \mathrm{~cm}^{-1}$ were due to the stretching vibration of alkyl $\left(-\mathrm{CH}_{2}-\right)$ group. The peak at $2593 \mathrm{~cm}$ ${ }^{1}$ was assigned to be a free SH. The presence of a weak broadband centred at $1644 \mathrm{~cm}-1$ wascharacteristic of the amide bond in proteins and indicates a small concentration of protein in the silver nanoparticle solution synthesised using the $S$. fusiformis extract (Fig. 3). The band at $1416 \mathrm{~cm}^{-1}$ was due to the $\mathrm{CH}_{2}$ bending. The band at $1170 \mathrm{~cm}^{-1}$ assigned to the secondary cyclic alcohols. The band at $749 \mathrm{~cm}^{-1}$ may be assigned as- $\mathrm{CH}=\mathrm{CH}-(\mathrm{cis})$ bends (Table 1).

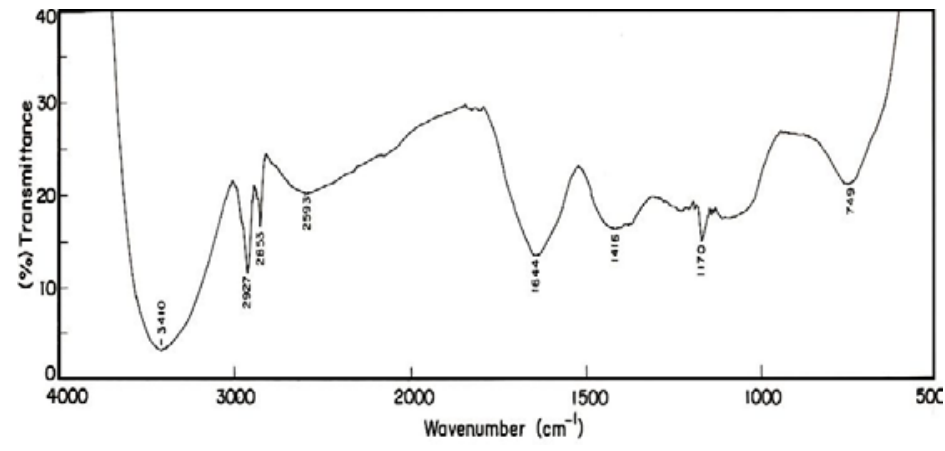

Fig. 3: FT-IR spectra of silver nanoparticles synthesized by the aqueous extract of $S$. fusiformis 
Table 1: FT-IR spectral interpretation of silver nanoparticles in S. fusiformis

\begin{tabular}{ll}
\hline Assignments & Wavenumber $\left(\mathbf{c m}^{-1}\right)$ \\
\hline OH stretching vibrations & 3907 \\
OH stretching vibrations & 3779 \\
N-H Stretching vibrations & 3410 \\
$\mathrm{CH}_{2}$ & 2853 \\
Free SH & 2593 \\
(C=OStretching vibrations) Amides & 1644 \\
$\mathrm{CH} 2$ & 1416 \\
Secondary Cyclic Alcohols & 1170 \\
$-\mathrm{CH}=\mathrm{CH}-($ cis) & 749 \\
\hline
\end{tabular}

\section{HR-TEM analysis}

The HR-TEM measurements were recorded on drop coated films of the Ag nanoparticles synthesised using S. fusiformis (Fig. 4).

The various shape and size distributions of synthesised silver nanoparticles were clearly observed in the HR-TEM analysis. Fig. 4 shows the HR-TEM ascertained morphology and size of the red seaweed $S$. fusiformis treated with a $10^{-3} \mathrm{M}$ silver nitrate solution for
24 h. The HR-TEM images of $S$. fusiformis synthesised silver nanoparticles showed mostly large and small spherical, triangle, pseudo-spherical and some in rounded rectangle shapes.

The micrograph showed the nanoparticles with variable shape, most of them present in spherical shape within the size range of 5 to 50 $\mathrm{nm}$. The size distribution of the silver nanoparticles is shown in fig. 5. The average size of the nanoparticles was found to be $32.70 \mathrm{~nm}$ as observed from the HR-TEM images.

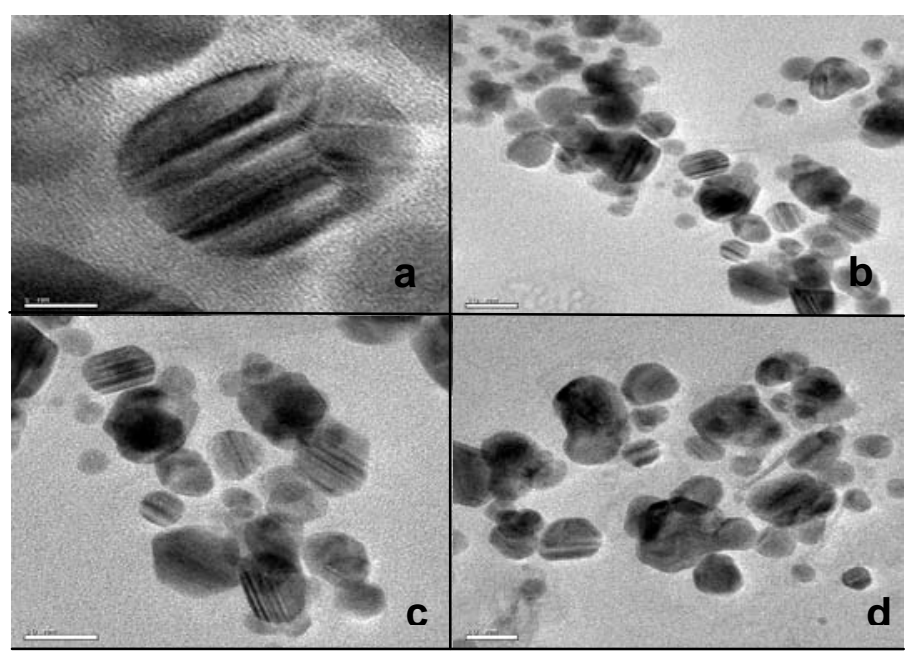

Fig. 4: HR-TEM images of the silver nanoparticles synthesized by using $S$. fusiformis

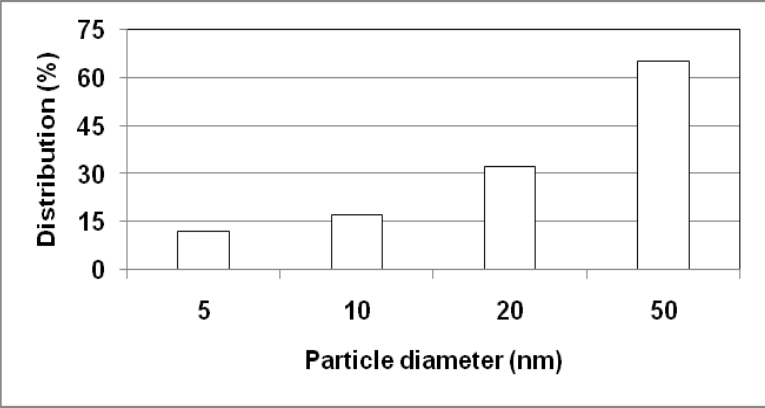

Fig. 5: A particle size distribution histogram of synthesized silver nanoparticles determined from HR-TEM images of $S$. fusiformis

\section{XRD analysis}

XRD is a widely used technique to elucidate the structure, crystalline nature and to estimate the purity of nanoparticles synthesized.

X-ray diffractogram of the biosynthesized Nano silver exhibits Bragg reflections, corresponding to face-centered cubic (FCC) type bulk silver.

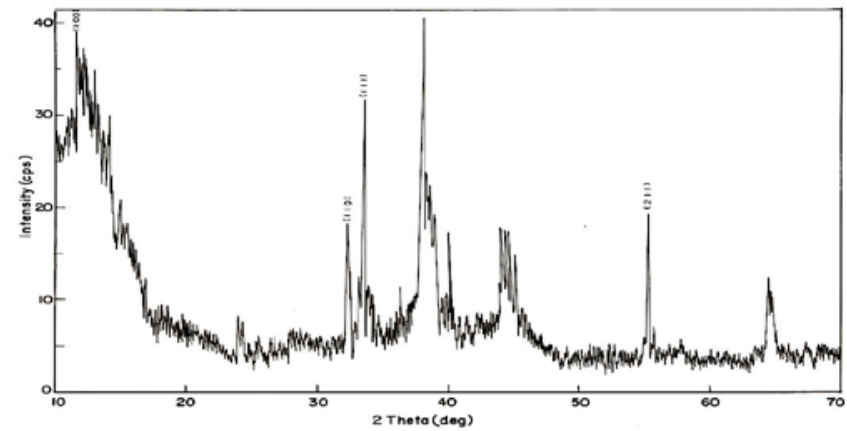

Fig. 6: X-ray diffraction pattern of the silver nanoparticles obtained from $S$. fusiformis

These XRD peaks indicate that the silver nanoparticles are crystalline in nature. In $S$. fusiformis, the XRD pattern of $2 \theta=11.62^{\circ}$, $32.19^{\circ}, 34.12^{\circ}$ and $55.12^{\circ}$ (Fig. 6) are in agreement with the Joint Committee on Powder Diffraction Standards (file No. 04-0783), which further proves the formation of crystal silver nanoparticles. The presence of intense peaks of silver nanoparticles corresponding to the $\left\{\begin{array}{lll}1 & 0 & 0\end{array}\right\},\left\{\begin{array}{lll}1 & 1 & 0\end{array}\right\},\left\{\begin{array}{ll}1 & 11\end{array}\right\}$ and $\left\{\begin{array}{lll}2 & 1 & 1\end{array}\right\}$ planes have been indexed as crystalline silver face-centered cubic (FCC) phase. 


\section{Antibacterial activities of crude extract and silver nanoparticles}

The antibacterial activity of the silver nanoparticle synthesized from S. fusiformis was tested against human bacterial pathogens (E. coli, $K$. pneumoniae, S. aureus and P. aeruginosa).

The antibacterial activity of the silver nanoparticles was carried out by the disc diffusion method and the zone of inhibition was measured.
The silver nanoparticles were synthesized by the marine red alga $S$. fusiformis at a higher concentration of $100 \mu \mathrm{g} / \mathrm{ml}$ which showed maximum zone of inhibition of $26 \mathrm{~mm}$ as observed in the $K$. pneumoniae followed by $S$. aureus $(24 \mathrm{~mm})$ when compared to the standard drug streptomycin (table 2; fig. 7), which shows only $18 \mathrm{~mm}$ of zone inhibition. In the case of the experimental alga $S$. fusiformis, the MIC was determined as $250 \mu \mathrm{g} / \mathrm{ml}$ and MBC was $125 \mu \mathrm{g} / \mathrm{ml}$ against the pathogen K. pneumoniae.

Table 2: Antibacterial activity of silver nanoparticles of $S$. fusiformis

\begin{tabular}{|c|c|c|c|c|c|c|}
\hline \multirow{2}{*}{$\begin{array}{l}\text { S. } \\
\text { No }\end{array}$} & \multirow[t]{2}{*}{ Name of the microorganisms } & \multicolumn{5}{|c|}{ Zone of inhibition in $\mathrm{mm}$ on human pathogen } \\
\hline & & $25 \mu \mathrm{g} / \mathrm{ml}$ & $50 \mu \mathrm{g} / \mathrm{ml}$ & $75 \mu \mathrm{g} / \mathrm{ml}$ & $100 \mu \mathrm{g} / \mathrm{ml}$ & $\begin{array}{l}\text { Streptomycin } \\
(100 \mu \mathrm{g} / \mathrm{ml})\end{array}$ \\
\hline 1 & E. coli & $12 \pm 0.003$ & $18 \pm 0.004$ & $20 \pm 0.006$ & $21 \pm 0.003$ & $16 \pm 0.002$ \\
\hline 2 & K. pneumoniae & $17 \pm 0.001$ & $20 \pm 0.006$ & $23 \pm 0.003$ & $26 \pm 0.007$ & $18 \pm 0.003$ \\
\hline 3 & S. aureus & $15 \pm 0.002$ & $17 \pm 0.001$ & $22 \pm 0.003$ & $24 \pm 0.004$ & $16 \pm 0.001$ \\
\hline 4 & P. aeruginosa & $19 \pm 0.003$ & $15 \pm 0.002$ & $20 \pm 0.006$ & $22 \pm 0.003$ & $17 \pm 0.001$ \\
\hline
\end{tabular}

Values are expressed as mean \pm SEM, $n=3$

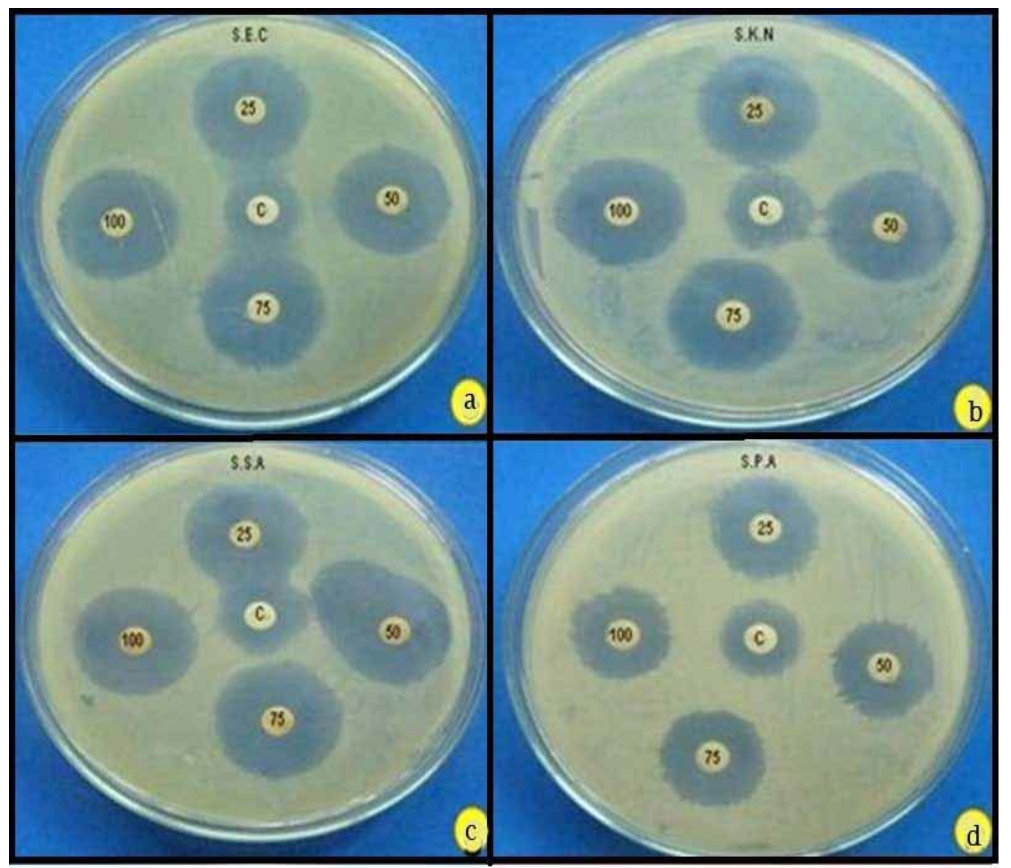

Fig. 7: Antibacterial activity of the silver nanoparticles synthesized from, S. fusiformis. a) Escherichia coli b) Klebsiella pneumonia, c) Staphylococcus aureus and d) Pseudomonas aeruginosa

\section{DISCUSSION}

In the present study, a green synthesis of silver nanoparticles using S. fusiformis has been carried out. It is observed that the colour of the solution turned from colourless to brownish yellow after $2 \mathrm{~h}$ of the reaction, indicating the formation of silver nanoparticles. This observation indicates that the reduction of the $\mathrm{Ag}^{+}$ions takes place extracellularly. The colour of the seaweed $S$. fusiformis extract becomes turbid after the addition of aqueous $\mathrm{AgNO}_{3}$ solution signifying the initiation of the reaction [13]. The appearance of brown colour was due to the excitation of surface Plasmon vibrations, typical of silver nanoparticles [8, 14, and 15]. The UVvisible absorption spectrum of the reaction mixture was analyzed at different wavelengths ranging from 400 to $700 \mathrm{~nm}$. The characteristic absorption peak at $450 \mathrm{~nm}$ in UV-Visible spectrum confirmed the formation of AgNPs $[16,17]$. The broad peak indicates the presence of nanoparticles with a large size distribution as well as polydispersity nature of the particle [18]. The Plasmon resonance bands of silver nanoparticles are broad with an absorption tail in the longer wavelength that extends well into the near-infrared region attributing the excitation of the in-plane SPR and indicates considerable anisotropy in the shape of silver nanoparticles. According to the Mie theory (1908), the small size and spherical shape of nanoparticles, which were formed in the reaction mixture were identified by forming a single SPR band for silver nanoparticles $[19,20]$. The intensity of the band increased upon varying the time without any shift in peak position. The attribute surface Plasmon absorption bands are noticed between 430 to 450 $\mathrm{nm}$ and rising of nanoparticle size can also affect the SPR band broadening [21]. Based on the high intensity, we confirmed that the surface Plasmon resonance was eminent.

Similarly, Ghodake and Lee (2011) reported that the SPR band was located at $530 \mathrm{~nm}$ for gold nanoparticle synthesized using brown algae Lonicera japonica [22]. FT-IR analysis was carried out to identify the possible biomolecule responsible for the reduction of the silver ion and capping agent of bio-reduced silver nanoparticles by $S$. fusiformis. The shift in peak clearly attributes the reduction of silver ions into nanoparticles. These records indicate the formation of silver ions due to a bio-reduction and their possible stabilization 
as nanoparticles. Since a member of $(\mathrm{NH}) \mathrm{C}=\mathrm{O}$ group within the cage of cyclic peptides is involved in stabilizing the nanoparticle, the shift of $(\mathrm{NH}) \mathrm{C}=\mathrm{O}$ band is quite small. Thus, the peptides play a major role in the reduction of $\mathrm{Ag}^{+}$of $\mathrm{Ag}$ nanoparticles. Bands at $1016 \mathrm{~cm}^{-1}$ are assigned as absorption peak of-C-O-C. The band at $1416 \mathrm{~cm}^{-1}$ in the silver nanoparticle spectrum may be attributed to- $\mathrm{C}-\mathrm{O}$ is stretching mode [23-26]. A broad IR band around $1512 \mathrm{~cm}^{-1}$ in the spectrum of silver nanoparticle arose from the stretching vibrations of the $\mathrm{C}=\mathrm{C}$ chain [27]. Hence, it may be inferred that these biomolecules are responsible for capping and efficient stabilization. The peak at 1644 $\mathrm{cm}^{-1}$ indicates the presence of $\mathrm{C}=0[28,29]$. A strong absorption peak at $3,430 \mathrm{~cm}^{-1}$ indicates the presence of phenols and alcohols with the free $0-\mathrm{H}$ group. The peak at $1,644 \mathrm{~cm}^{-1}$ represents the presence of amide I group and may well arise due to the carbonyl stretch in proteins [17]. Absorbance bands were seen at $3410 \mathrm{~cm}^{-1}$ were assigned to the stretching vibrations of primary and secondary amines, respectively. The result revealed that the capping ligand of the AgNPs may be an aromatic compound or alkanes or amines. These findings support the results of Gole et al., [30] which states that proteins can bind to nanoparticles either through free amine groups or cysteine residues and therefore the stabilization of the silver nanoparticles by protein occurs [30]. The biological molecules such as secondary metabolites could possibly perform the dual functions of formation and stabilization of silver nanoparticles in the aqueous medium [31, 32]. The High-Resolution Transmission electron microscopy (HR-TEM) is the technique used to determine the size and size distribution of nanoparticle samples [33]. HR-TEM images clearly revealed the formation of spherical and rounded rectangle like structures. The size of the nanoparticle is around 5-50 $\mathrm{nm}$. The similar results were observed by Murugesan et al., when using red alga Gracilaria edulis as a reducing as well as capping agent [34]. The average size of resulting particles is about 32.70 to $38.70 \mathrm{~nm}$. It is well known that the shape of metallic nanoparticles considerably changed their optical and electronic properties as reported earlier by [35, 36] Shipway et al., (2000); Nie and Emory (1997). When compared to the previous reports of [37, 38] Noruzi et al., and Raghunandan et al., states that the algal-mediated silver nanoparticle shape varies as spherical triangle, and pseudospherical [35-38]. The coating material is believed to be a bioorganic component of $S$. fusiformis. The X-ray diffraction patterns obtained for the silver nanoparticles which are synthesized using $S$. fusiformis extract a number of Bragg reflections with $2 \theta$ values of $11.63^{\circ}, 32.20^{\circ}, 34.13^{\circ}$ and $55.13^{\circ}$ sets of lattice planes are observed which may be indexed in the $\left\{\begin{array}{lll}1 & 0 & 0\end{array}\right\},\left\{\begin{array}{lll}1 & 1 & 0\end{array}\right\},\left\{\begin{array}{lll}1 & 11\end{array}\right\}$ and $\{2$ $11\}$ faces of silver and respectively, which confirms the facecentered cubic structure of the formed silver nanoparticles. X-Ray diffraction pattern thus clearly illustrates that the silver nanoparticles formed in this present study are crystalline in nature. The antibacterial behaviours of silver nanoparticles from marine red alga $S$. fusiformis provide the great expectations in pathogenic microbe controlling by advance technology. The antibacterial activity was conducted against the human pathogenic bacteria $E$. coli, S. aureus, K. pneumoniae and P. aeruginosa. The antibacterial effect of silver nanoparticles was studied by using the disc diffusion method. Pal et al., (2007) reported that the shape of the silver nanoparticle could influence antimicrobial activity [39]. The zone of inhibition clearly indicates the promising effect of biosynthesized silver nanoparticles than the chemically synthesized nanoparticles. Stoimeno et al., (2002) demonstrated that the highly reactive metal oxide nanoparticles exhibit excellent biocidal activity against Grampositive and Gram-negative bacteria [40]. Aymonier et al., (2002) showed that hybrids of silver nanoparticles with amphiphilic hyperbranched macromolecules exhibit effective antimicrobial surface coatings [41]. It is believed that DNA loses its replication ability and cellular proteins become inactivated on $\mathrm{Ag}^{+}$treatment [42]. It was also shown that $\mathrm{Ag}^{+}$binds to functional groups of proteins, resulting in protein denaturation [43]. Some studies have reported that the positive charge of the Ag ions is crucial for its antimicrobial activity through the electrostatic attraction between negatively charged cell membranes of microorganism and positively charged nanoparticles [40-42]. The nanoparticles were reacted with the bacterial cell walls and inhibit the growth of the bacteria vigorously and formed the zone size. The present study shows that the algal assisted synthesis of silver nanoparticles from S. fusiformis against the different bacterium $E$. coli and $K$. pneumonia has a towering inhibition and got decreased gradually against $S$. aureus and $P$. aeruginosa respectively, whereas silver nanoparticles have more or less similar effect on the bacteria. The mode of the bactericidal activity of silver nanoparticle is depending on the source from which the particles derived [44].

The silver nanoparticle has various modes of action when invaded to microbes. It depends on different parameters like source, concentration and contact time, nature of microbe, temperature and $\mathrm{pH}$. The exact mechanisms of silver nanoparticles against the bacterial culture are clearly known and the small surface area containing nanoparticles having interaction with the large surface area may attach the cell membrane of the bacteria and involve the process of upsetting the respiration and permeability. The adsorption on the bacterial surface and intracellular enzyme activity is the main reason for the antibacterial reactions.

\section{CONCLUSION}

The extract of marine red seaweed $S$. fusiformis is capable of producing silver nanoparticles as observed from our investigation. The synthetic method using algal sources is an environmentally benign process and the algal extracts can be used as an effective capping as well as a reducing agent for the synthesis. The AgNPs showed potential antibacterial activity against human pathogens like E. coli, S. aureus, K. pneumoniae and P. aeruginosa. Applications of these eco-friendly nanoparticles with bactericidal and other medical applications will have a high potential for large-scale synthesis in future.

\section{ACKNOWLEDGMENT}

The financial support received from University Grants Commission, New Delhi (Grant No. F1-17.1/2011-12/RGNF-SC-TAM-5342/(SAIII/Website) dated 6/6/12) is gratefully acknowledged.

\section{AUTHOR CONTRIBUTION}

S. Murugesan contributed for overall work design, results in interpretation and manuscript preparation

S. Bhuvaneswari contributed for algae collection, extraction and nanoparticles synthesis and biological studies

V. Sivamurugan contributed for spectral chracterisation, interpretation of results and manuscript preparation

\section{CONFLICT OF INTERESTS}

The authors declare that they have no conflict of interest

\section{REFERENCES}

1. Rajasulochana $P$, Dhamotharan $R$, Murugakoothan $P$, Murugesan S, Krishnamoorthy P. Biosynthesis and characterization of gold nanoparticles using the alga Kappaphycusalvarezii. Int J Nanoscience 2010;9:511-5.

2. Swaminathan S, Murugesan S, Damodarkumar S, Dhamotharan R, Bhuvaneswari S. Synthesis and characterization of gold nanoparticles from alga Acanthophoraspecifera (VAHL) boergesen. Int J Nanosci Nanotech 2011;2:85-94.

3. Bhuvaneswari S, Murugesan S, Sridharan MC, Dhamotharan R, Murugakoothan P. Turbinariaconoides: a novel biological agent for the extracellular synthesis of gold nanoparticles. Proceedings of International Conference on Implications of Biotechnology on Biodiversity and its Conservation January 27 and 28, 2011. Suppl Adv Biotech 2011;10:107-10.

4. Murugesan S, Elumalai M, Dhamotharan R. Green synthesis of silver nanoparticles from marine alga Gracilariaedulis S. G (Gmelin) P. C. Silva. Biosci Biotech Res Comm 2011;4:105-10.

5. Radhika D, Veerabahu C, Sakthibama G, Murugesan S. Green synthesis of gold nanoparticles by the marine alga Stoechospermummarginatum. Int $\mathrm{J}$ Nanosci Nanotech 2012;6:61-70.

6. Dhamotharan R, Sridevi H, Murugesan S, Murugakootan P. Biosynthesis and characterization of gold nanoparticles from 
marine alga Sargassumswartzii C. Agarth. Int J Appl Sci Nanotech 2012;1:21-8.

7. Dhamotharan R, Punitha D, Murugesan S, Subha TS. Brown algal biomass mediated biosynthesis of gold nanoparticles. Int J Nanosci Nanotech 2010;1:37-44.

8. Thennarasan S, Murugesan S. Biosynthesis of silver nanoparticles using marine brown alga Lobophora variegate and assessment of its bactericidal activity. Int J Nanosci Nanotech 2014;5:39-47.

9. Vishnu Kiran M, Murugesan S. Biosynthesis of silver nanoparticles from marine alga Halymeniaporyphyroidesand its antibacterial efficacy. Int J Curr Microbiol App Sci 2014;3:96-103.

10. Murugesan S, Bhuvaneswari S, Shanthi N, Murugakoothan P, Sivamurugan V. Red alga Hypneamusciformis (Wulf) lamour mediated environmentally benign synthesis and antifungal activity of gold nanoparticles. Int J Nanosci Nanotech 2015;6:71-83.

11. Vinothkumar R, Murugesan S, Bhuvaneswari S. Extracellular synthesis of silver nanoparticles by a marine red alga Champiaparvula and their antibacterial activity. Therapeutics of marine bioactive compounds. Thahira Banu, A and Somishon Keishing. Educationalist Press: New Delhi; 2015. p. 218.

12. Maynard AD, Michelson E. The nanotechnology consumer product inventory; 2006. Available from: http://www.nanotechproject. org/44S. [Last accessed on 10 Dec 2015]

13. Nabikhan A, Kandasamy K, Raj A, Alikunhi NM. Synthesis of antimicrobial silver nanoparticles by callus and leaf extracts from saltmarsh plants, Sesuviumportulacastrum, L. Colloids Surf B Interface 2010;79:488-93.

14. Mulvancy P. Surface plasmon spectroscopy of nanosized metal particles. Langmuir 1996;12:788-800.

15. Govindaraju K, Tamilselvan S, Kiruthiga V, Singaravelu G. Biogenic silver nanoparticles by Solanumtorvum and their promising antimicrobial activity. J Biopesticides 2010;3:394-9.

16. Henglein A. Physicochemical properties of small metal particles in solution: "microelectrode" reactions, chemisorptions, composite metal particles, and the atom-to-metal transition. J Phys Chem 1993;97:5457-71.

17. Kumar P, Senthamil Selvi S, Lakshmi Praba A, Prem Kumar K, Ganeshkumar RS, Govindaraju M. Synthesis of silver nanoparticles from Sargassumtenerrimum and screening phytochemicals or its anti-bacterial activity. Nano Biomed Eng 2012;4:12-6.

18. Kamat PV, Flumiani M, Hartland GV. Picosecond dynamics of silver nanoclusters. Photoejection of electrons and fragmentation. J Phys Chem B 1998;102:3123-8.

19. Mie G. Beiträgezur optiktrüber medien, speziellkolloidaler metallösungen. Ann Physik 1908;25:377.

20. Smitha SL, Philip D, Gopchandran KG. Green synthesis of gold nanoparticles using Cinnamomumzeylanicum leaf broth. Spectrochim Acta Part A 2009;74:735-9.

21. Harekrishna B, Dipak KB, Gobinda PS, Priyanka S, Santanu P, Ajay M. Green synthesis of silver nanoparticles using seed extract of Jatropha curcas. Colloids Surf A 2009;348:212-6.

22. Ghodake G, Lee DS. The biological synthesis of gold nanoparticles using the aqueous extract of the brown algae Laminaria japonica. J Nanoelectron Optoe 2011;6:1-4.

23. Shankar SS, Ahmad A, Sastry M. Geranium leaf assisted biosynthesis of silver nanoparticles. Biotechnol Prog 2003;19:1627-31.

24. Huang J, Liu Y, Wang X. Selective adsorption of tannin from flavonoids by organically attapulgite clay. J Hazardous Mater 2008; $160: 382-7$.

25. Philip D. Biosynthesis of $\mathrm{Au}, \mathrm{Ag}$ and $\mathrm{Au}-\mathrm{Ag}$ nanoparticles using edible mushroom extract. Spectrochim Acta A 2009;73:374-81.

26. Philip D. Honey mediated green synthesis of gold nanoparticles. Spectrochim Acta A 2009;73:650-3.

27. Schulz H, Baranska M. Identification and quantification of valuable plant substances by IR and Raman spectroscopy. Vib Spectros 2007;43:13-6.
28. O'Coinceanain MO, Astill C, Schumm S. Potentiometric FTIR and NMR studies of the complexation of metals with theaflavin. Dalton Trans 2003;5:801-7.

29. Shetty G, Kedall C, Shepherd N, Stone N, Barr H. Raman spectroscopy: elucidation of biochemical changes in carcinogenesis of the oesophagus. Br J Cancer 2006;94:1460-4.

30. Gole A, Dash C, Ramakrishnan V, Sainkar SR, Mandale AB, Rao M. Pepsom gold colloid conjugates preparation, characterization and enzymatic activity. Langmuir 2001; 17:1674-9.

31. Sathyavathi R, Krishna MB, Rao SV, Rao DN. Biosynthesis of silver nanoparticles using Coriandrumsativum leaf extract and their application in non-linear optics. Adv Sci Lett 2010;3:13843.

32. Rashmi S, Preeti V, Sadhna P. Enzymatic formation of gold nanoparticles using Phanerochaetechrysosprium. Adv Chem Eng Sci 2011;1:154-62.

33. Ahmad A, Mukherjee P, Senapati S, Mandal D, Khan MI, Kumar R. Extracellular biosynthesis of silver nanoparticles using the fungus Fusariumoxysporum. Colloids Surf B 2003;28:313-8.

34. Murugesan S, Elumalai M, Dhamotharan R. Green synthesis of silver nanoparticles from marine alga Gracilaria edulis S. G (Gmelin) P.C. Silva. Biosci Biotech Res Comm 2011;4:105-10.

35. Shipway AN, Katz E, Willner I. Nanoparticle arrays on surfaces for electronic, optical, and sensor applications. Chem Phys Chem 2000;1:18.

36. Nie S, Emory SR. Probing single molecules and single nanoparticles by surface-enhanced raman scattering. Science 1997;275:1102.

37. Noruzi M, Zare D, Khoshnevisan K, Davoodi D. Rapid green synthesis of gold nanoparticles using Rosa hybrid petal extract at room temperature. Spectrochimica Acta Part A 2011;79:1461-5.

38. Raghunandan D, Basavaraja S, Mahesh B, Balaji S, Manjunath SY, Venkataraman A. Biosynthesis of stable poly shaped gold nanoparticles from microwave-exposed aqueous extracellular anti-malignant guava (Psidiumguajava) leaf extract. Nano Biotechnol 2009;5:34-41.

39. Pal S, Tak YK, Song JM. Does the antimicrobial activity of silver nanoparticles depend on the shape of the nanoparticle? A study of the gram-negative bacterium Escherichia coli. Appl Environ Microbiol 2007;73:1712-20.

40. Stoimenov PK, Klinger RL, Marchin GL, Klabunde KJ. Metal oxide nanoparticles as bactericidal agents. Langmuir 2002;18:6679-86.

41. Aymonier C, Schlotterbeck U, Antonietti L, Zacharias $\mathrm{P}$, Thomann R, Tiller J. Hybrids of silver nanoparticles with amphiphilic hyperbranched macromolecules exhibiting antimicrobial properties. Chem Commun (Camb) 2002;24:3018-9.

42. Feng QL, Wu J, Chen GQ, Cui FZ, Kim TM, Kim JO. A mechanistic study of the antibacterial effect of silver ions on Escherichia coli and Staphylococcus aureus. J Biomed Mater Res 2000;52:662-8.

43. Spadaro JA, Berger TJ, Barranco SD, Chapin SE, Becker RO. Antibacterial effects of silver electrodes with the weak direct current. Antimicrob Agents Chemother 1974;6:637-42.

44. Karthick R, Namasivayam S, Abimanyu. Silver nanoparticle synthesis from Lecanicilliumlecanii and evolutionary treatment on cotton fabrics by measuring their improved antibacterial activity with antibiotics against Staphylococcus aureus (ATCC 29213) and E. coli (ATCC 25922) strains. Int J Pharm Pharm Sci 2011;3:190-5.

\section{How to cite this article}

- Subbiah Murugesan, Sundaresan Bhuvaneswari, Vajiravelu Sivamurugan. Green synthesis, characterization of silver nanoparticles of a marine red alga spyridia fusiformis and their antibacterial activity. Int J Pharm Pharm Sci 2017;9(5):192-197. 